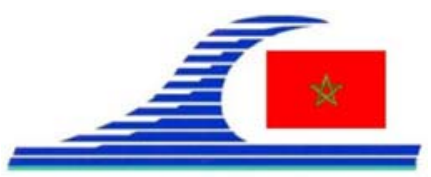

\title{
Mineralogy and compaction properties of dredged marine sediments
}

\author{
Dongxing WANG ${ }^{1,2}$, Nor Edine ABRIAK ${ }^{1}$, Rachid ZENTAR ${ }^{1}$
}

1. Ecole des Mines de Douai, MPE-GCE, 59500 Douai, France.

2. Hohai University, Institute of Civil Engineering, 210098 Nanjing, China. dongxing.wang@mines-douai.fr

\begin{abstract}
:
In the context of sustainable development, traditional solutions such as sea dumping will be more and more regulated. Coupled with the shortage of granular materials from quarries, dredged sediments constitute a solution for public works. To evaluate the potential uses of dredged marine sediment in road construction, the physical, mineralogical and compaction characteristics were discussed. Firstly, the physical characteristics were dealt with. Secondly, the X-ray diffraction analysis and the X-ray fluorescence analysis were performed to determine the crystalline phases and the chemical elements. Finally, the immediate bearing capacity ratio was measured to explore the potential of raw sediments as road construction material. Then, different stabilizers were tested to improve the road layer bearing capacity of sediments.
\end{abstract}

Key-words:

Dredged sediment - Physical property - Mineralogical analysis - Bearing capacity ratio- Lime and cement

\section{Introduction}

Now, the protection of marine environment is attracting more and more the attention of many countries in the world. Therefore, traditional methods such as ocean dumping are being gradually discarded by developed and developing countries. In France, more than 50 million $\mathrm{m}^{3}$ of sediments are dredged each year, and more than 365 million tons of granular materials are consumed (DUBOIS, 2006). Consequently, how to deal with so much sediment in view of safe navigation is a very challenging issue.

One solution is to reuse these sediments in the construction area, such as brick production (HAMER \& KARIUS, 2002), and road engineering (ONITSUKA and SHEN, 1999, COLIN, 2003, DUBOIS, 2006, ZENTAR et al., 2008, TRAN, 2009). Combined with a shortage of construction materials in civil engineering and public works, a new solution to produce a special road material based on dredged sediments in road engineering is more and more proposed.

In this paper, the marine sediment of Dunkirk Port is studied for a potential use as a material in road layers. Specific objectives are: (1) to determine the physical characteristics of dredged sediments; (2) to study their mineralogical nature; (3) to 
La connaissance de la Mer :

un vecteur du développement durable en Méditerranée

evaluate the compaction properties of raw sediments and treated sediments and their potential use in road construction.

\section{Materials and Methods}

\subsection{Materials}

The marine sediments tested were dredged from Dunkirk Harbour in France in 2008. The dredged materials were stored in sealed plastic buckets of $0.054 \mathrm{~m}^{3}$ in volume. The dredged sediment is black and unpleasant due to the presence of organic matter.

Cement CEM I 42.5R HSR LA is used to form a new material resistant to traffic and climatic stresses. Lime, named Lhoist PROVIACAL ST, which is produced in Belgium, is used owing to its low cost.

\subsection{Methods}

Tests concern physical characteristics according to French standards, such as initial water content, particle size distribution, organic matter content, absolute density, methylene blue value, liquid limit and plastic limit. And then, to improve the mechanical characteristics and enhance the performance for road sub-layer material, cement and lime are chosen.

\section{Results}

\subsection{Sediment characterization}

Test results of Dunkirk sediments are given in table 1. For the sediment, the initial water content is $148.5 \%$, measured by drying at $40^{\circ} \mathrm{C}$. The absolute density is $2.58 \mathrm{~g} / \mathrm{cm}^{3}$, obtained by using an helium pycnometer. The methylene blue value is equal to 2.2 $\mathrm{g} / 100 \mathrm{~g}$. The organic matter content, determined by the ignition test at $550^{\circ} \mathrm{C}$, is $12.8 \%$. The sediment is composed of clay, silt and sand, and their fractions are respectively 8.0\%, $80.8 \%$ and $11.2 \%$. The liquid limit $\left(\mathrm{L}_{\mathrm{L}}\right)$ measured by the percussion cup method is $86.2 \%$, and the plastic limit $\left(\mathrm{L}_{\mathrm{P}}\right)$ is $34.3 \%$ determined by the rolling method.

\subsection{X-Ray Diffraction and X-Ray Fluorescence analysis}

To detail the nature of every component of sediments, X-Ray Diffraction (XRD) and XRay Fluorescence (XRF) analyses were carried out. Three main crystalline phases: quartz, calcite and halite, are detected by X-Ray diffraction technique (see figure 1).

$\mathrm{X}$-Ray fluorescence test is used to determine the chemical elements in sediments, listed in table 2. The main elements observed in the sediments are silicon, calcium and oxygen, and this corresponds well with the XRD test results. 
A best knowledge of the Sea:

A sustainable development vector in Mediterranean

Table 1. Physical and chemical characteristics of Dunkirk dredged marine sediments.

\begin{tabular}{|c|c|c|}
\hline \multicolumn{2}{|l|}{ Parameters } & Values \\
\hline \multicolumn{2}{|c|}{ Initial water content (\%) } & 148.5 \\
\hline \multicolumn{2}{|c|}{ Absolute density $\left(\mathrm{g} / \mathrm{cm}^{3}\right)$} & 2.58 \\
\hline \multicolumn{2}{|c|}{ Methylene blue value $(\mathrm{g} / 100 \mathrm{~g})$} & 2.2 \\
\hline \multicolumn{2}{|c|}{ Organic matter content (\%) } & 12.8 \\
\hline \multirow{3}{*}{$\begin{array}{l}\text { Particle size } \\
\text { distribution }\end{array}$} & Clay $(<2 \mu m)$ & 8.0 \\
\hline & Silt (2 to $63 \mu \mathrm{m}$ ) & 80.8 \\
\hline & Sand $(>63 \mu m)$ & 11.2 \\
\hline \multicolumn{2}{|l|}{$L_{L}(\%)$} & 86.2 \\
\hline \multicolumn{2}{|l|}{$L_{P}(\%)$} & 34.3 \\
\hline
\end{tabular}

Table 2. Elements analyzed by Fluorescence X (Unit: \%).

\begin{tabular}{lll}
\hline Elements & Symbol & Concentration \\
\hline Oxygen & $\mathrm{O}$ & 49.7 \\
Silicon & $\mathrm{Si}$ & 16.4 \\
Calcium & $\mathrm{Ca}$ & 15.1 \\
Aluminium & $\mathrm{Al}$ & 4.7 \\
Iron & $\mathrm{Fe}$ & 4.1 \\
Chlorine & $\mathrm{Cl}$ & 2.8 \\
Sodium & $\mathrm{Na}$ & 2.1 \\
Magnesium & $\mathrm{Mg}$ & 1.2 \\
Sulfur & $\mathrm{S}$ & 1.5 \\
Potassium & $\mathrm{K}$ & 1.6 \\
Titanium & $\mathrm{Ti}$ & 0.3 \\
Phosphor & $\mathrm{P}$ & 0.1 \\
Copper & $\mathrm{Cu}$ & Trace \\
Zinc & $\mathrm{Zn}$ & 0.1 \\
Manganese & $\mathrm{Mn}$ & Trace \\
Lead & $\mathrm{Pb}$ & Trace \\
Chromium & $\mathrm{Cr}$ & Trace \\
Barium & $\mathrm{Ba}$ & Trace \\
Zirconium & $\mathrm{Zr}$ & Trace \\
Bromine & $\mathrm{Br}$ & Trace \\
Strontium & $\mathrm{Sr}$ & Trace \\
\hline & $\mathrm{Trace}=$ percent<0.1\% &
\end{tabular}


La connaissance de la Mer :

un vecteur du développement durable en Méditerranée

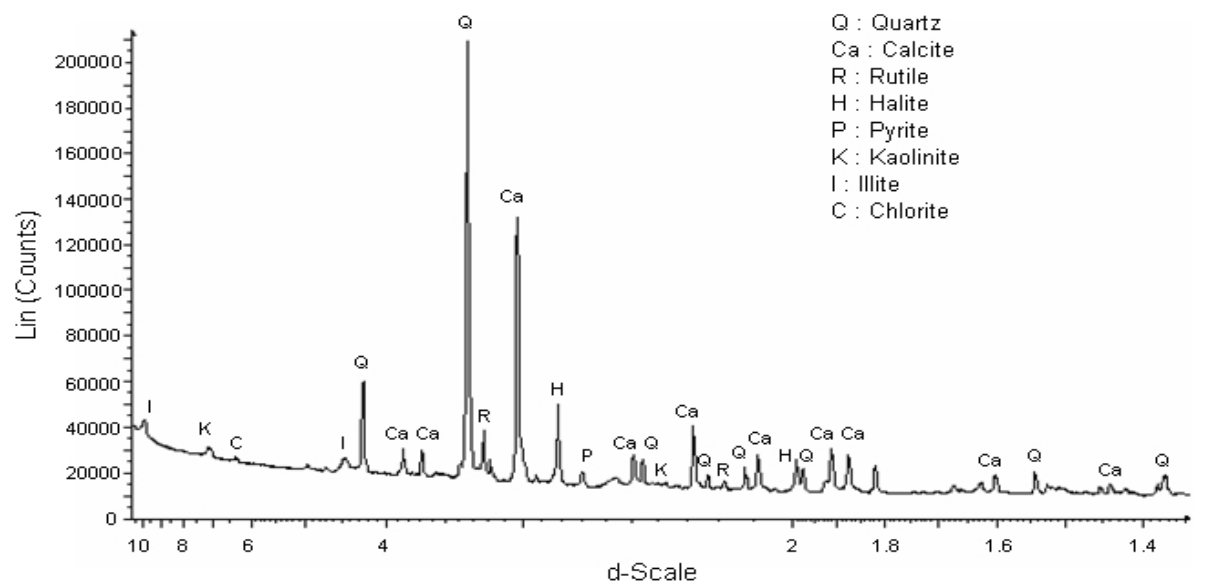

Figure 1. Crystal phase of Dunkirk dredged sediments.

\subsection{Improvement of road bearing capacity}

Modified Proctor compaction test results in combination with the I-CBR curve, are shown in figures 2(a) and 2(b) for raw sediments and treated sediments. The I-CBR value of raw sediments is $24 \%$ at the optimum water content. This value is lower than the prescribed value for a sub-base material (optimal value: 35\%, minimum value: $25 \%)$. So, how to enhance the I-CBR value of the dredged sediment is a very difficult issue. For this study, the addition of cement or lime is the proposed solution.

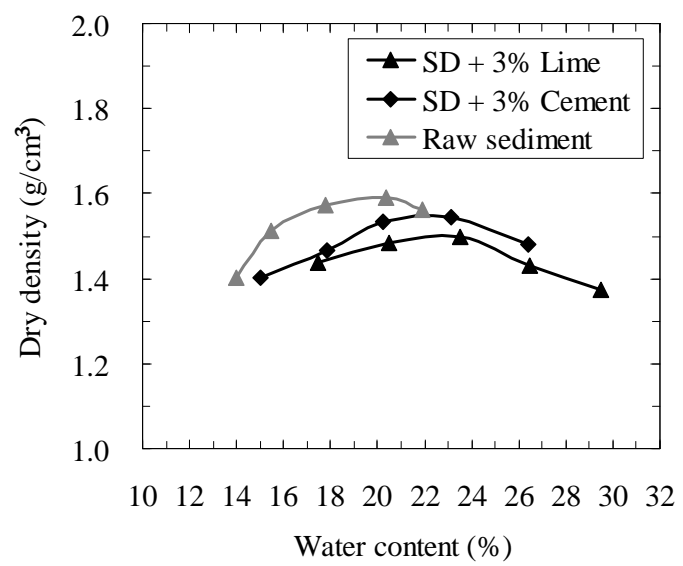

(a): Compaction

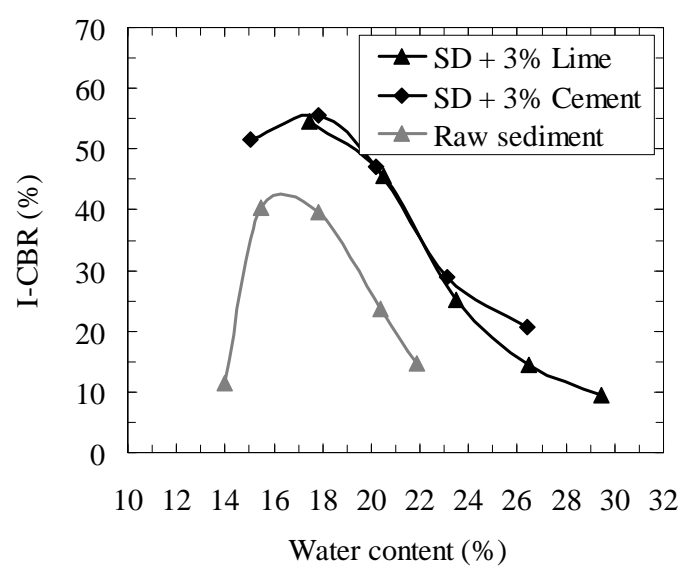

(b): $I-C B R$

Figure 2. Evolution of modified Proctor compaction and I-CBR of treated sediments. 
In order to reuse the dredged sediments in road sub-layer, $3 \%$ cement or $3 \%$ lime could be mixed with sediments to improve the bearing capacity. After addition of $3 \%$ cement, the improved I-CBR value is $34.6 \%$ at the optimum water content, which could almost reach the requirement of the road sub-layer material. So, the sediments treated with $3 \%$ cement could be considered for the road sub-layer material. For sediments treated with $3 \%$ lime, the I-CBR value is $29.4 \%$ at the optimum water content, which is higher than the minimum I-CBR value of sub-layer material. So, the dredged sediments with $3 \%$ lime could be used as a road sub-layer material.

\section{Conclusion}

The physical, mineralogical and compaction properties of dredged sediments were studied to evaluate the potential use of the dredged sediment in road construction. The physical characteristics have been performed according to French and European norms. The mineral crystals and chemical elements were analyzed by the X-Ray Diffraction and X-Ray Fluorescence analysis. Three main crystalline phases are quartz, calcite and halite, and the main elements of sediments are silicon, calcium and oxygen. To improve the engineering properties of the dredged sediments, 3\% lime and 3\% cement were separately added into the dredged materials. According to the I-CBR values, it seems that the dredged sediment treated with $3 \%$ cement can be used as a road sub-layer material, and the sediments treated with $3 \%$ lime can be used as a road sub-layer material.

\section{Acknowledgement}

This research was undertaken with a financial support of the China Scholarship Council.

\section{References}

COLIN D. (2003). Valorisation de sédiments fins de dragage en technique routière. Thèse, Université de Caen, France.

DUBOIS V. (2006). Caractérisation physico-mécanique et environnementale des sédiments marins. Application en technique routière. Thèse, Ecole des Mines de Douai, France.

HAMER K., KARIUS V. (2002). Brick production with dredged harbour sediments: An industrial-sacle experiment. Waste Management, $\mathrm{n}^{\circ} 22$, pp 521-530.

ONITSUKA K., SHEN J. (1999). Evaluation of lime-stabilized Ariake clay with foaming waste glass as pavement materials. International Journal of Pavement Engineering, $\mathrm{n}^{\circ} 1$.

TRAN N. (2009). Valorisation de sédiments marins et fluviaux en technique routière. Thèse, Ecole des Mines de Douai, France. 
La connaissance de la Mer :

un vecteur du développement durable en Méditerranée

ZENTAR R., DUBOIS V., ABRIAK N.E. (2008). Mechanical behaviour and environmental impacts of a test road built with marine dredged sediments. Resources, Conservation and Recycling, $\mathrm{n}^{\circ}$ 52, pp 947-954. doi:10.1016/j.resconrec.2008.02.002 